\title{
Livelihood Strategies of Female Indigenous Vegetable Farmers' in Osun State, Nigeria
}

\author{
Adeolu B. Ayanwale ${ }^{1} \&$ Christianah A. Amusan ${ }^{1}$ \\ ${ }^{1}$ Department of Agricultural Economics, Obafemi Awolowo University, Ile-Ife, Nigeria \\ Correspondence: Adeolu B. Ayanwale, Department of Agricultural Economics, Obafemi Awolowo University, \\ Ile-Ife 220005, Nigeria. Tel: 234-803-426-2584. E-mail: aayanwa@yahoo.co.uk
}

Received: March 28, 2014

Accepted: July 22, 2014 Online Published: September 15, 2014

doi:10.5539/jas.v6n10p96

URL: http://dx.doi.org/10.5539/jas.v6n10p96

\begin{abstract}
This study examined the socioeconomic characteristics, income profile and pattern of livelihood diversification strategies of resource-constrained female indigenous vegetable farmers in Osun state, which may serve as entry point for poverty alleviation and women empowerment in the study area.

A total of 240 female indigenous vegetable farmers were surveyed through the use of pre-tested structured questionnaire during the 2011/2012 production cycle. The study established that the majority of the respondents were below 50 years of age (73\%), married $(78 \%)$ with more than 7 years of formal education $(51.7 \%)$ and cultivated less than 1 hectare of vegetables $(65 \%)$. Vegetable production is the most important source of income contributing about half of the total income of the farmers but its share reduces as total income increases. Cluster analysis identified six livelihood portfolio combinations- sole vegetable farming, vegetable and livestock farming, part time vegetable and livestock farming, mixed farming, arable crop farming, part time mixed farming. Part time mixed farming was the most successful livelihood portfolio because it had the highest daily per capita income ( $378.55)$, the highest proportion of the rich $(72.73 \%)$ and the lowest proportion of the poor $(4.55 \%)$, while, vegetable and livestock farming was most common among the poorest farmers $(53.85 \%)$.

A major policy implication of the results of the study is that multiple complementary economic activities such as milling and other food processing activities should be encouraged among the female indigenous vegetable farmers, to enable them generate sufficient incomes to improve on their livelihood.
\end{abstract}

Keyword: diversification, female, indigenous, livelihood, vegetables

\section{Introduction}

Indigenous leafy vegetables enterprise holds the greatest potentials for the provision of additional sources of food, nutritional value, and income particularly for the rural resource-constraint women farmers in Nigeria. In many parts of Africa, indigenous vegetables are considered to be "women's crops" because they are mostly grown or gathered by women (Howard, 2003) for both domestic consumption and for sale in markets (Price \& Ogle, 2008). Gathering plants takes place in fields when crops are growing, in fallow fields and in areas of secondary growth (Price \& Ogle, 2008). This practice offers a significant opportunity for the poorest people to earn a living, as producers and traders without requiring large capital investments (Maroyi, 2011). Where indigenous vegetable is grown, its production is basically small-scale using traditional manual techniques. Production of indigenous vegetables often requires very little input save for occasional farmyard manure application and very rarely is chemical fertilizer used (Onyango, Imungi, Mose, Harbinson, \& Van Kooten, 2009).

Indigenous vegetables are also rarely affected by diseases and pests (Farm Concern International, 2011). It has been variously demonstrated that production of indigenous leafy vegetables as small scale enterprises can be viable (Besong, Samalang, \& Abia, 2001; Ngugi, Gitau, \& Nyoro, 2006) as it yields early returns (P. Joshi, L. Joshi, \& Birthal, 2006) and is more remunerative than cereals, pulses and other economic activities (Adhakari, 2006). The production of indigenous leafy vegetables has a comparative advantage under conditions where arable land is scarce and labour is abundant (Weinberger \& Lumpkin, 2005), often providing the only cash resource for women to use for the welfare of their families (AVRDC, 2011). The revenue generated contributes significantly to the enhancement of household food security, access to family health care and enables women to attain some degree of financial independence within the family budget (IITA, 2003). This has positive implications for immediate 
well-being as well as long-run human capital formation and economic growth through improved health, nutrition and education outcomes (Doss, 2005; Smith, Ramakrishnan, Ndiaye, Haddad, \& Martorell, 2003; Quisumbing \& Maluccio, 2000).

Notwithstanding the contribution to food security and its potential to provide supplementary income for resource-constraint women, indigenous vegetables remain under threat of being lost. This is due to poor harvesting methods such as uprooting or other harvesting methods which involve destroying the entire plant and harvesting the reproductive parts before or at seed formation (Luchen \& Mingochi, 1995). The leafy vegetables of Africa are being displaced in many areas, leading to a decline in production, use, and diversity of vegetables being grown (Aphane, Chadha, \& Oluoch, 2002). Adebooye and Opabode (2004) reported that the diversity of indigenous leaf vegetables and fruits of Africa is being seriously eroded as a result of multiplicity of environmental, political, and socio-economic factors. Farming practices and other critical factors such as land clearing for agriculture; urbanization, industrialization and population increase result in demand for land leading to the destruction of plants species. Lack of an efficient irrigation system, an assured market, storage facilities, appropriate infrastructure and non-availability of improved and good quality seed reduces profitability and increases production risk (Joshi et al., 2006). This trend clearly has a detrimental impact on the nutritional status of households, and the incomes of women farmers, in particular, who constitute the primary producers, consumers, and sellers of these vegetables (Aphane et al., 2002). These factors necessitated the diversification of livelihood for the female indigenous vegetable farmers in order to reduce income vulnerability since the potential of vegetable enterprise as a source of an all-year-round income cannot be guaranteed.

\subsection{Statement of the Research Problem}

Gathering and growing of indigenous vegetables is one of the means of generating income. However, indigenous vegetable production cannot completely meet the income need of the women growers because of constraints such as regular exploitation and destruction of natural forest to meet men's various need, reliance on rain-fed agriculture, lack of irrigation and storage facilities and market imperfection. The resultant effect is a seasonal fluctuation in income. Hence, female vegetable growers embark upon other economic activities in a bid to augment household income. Women are important in the production of food for the nation. In addition, the income that accrues to them from various economic activities has a great implication for the household wellbeing. Since these sources do not have the same potential contribution to their income, it is important to investigate them and their contribution to the income of the farmers.

Research attention on indigenous vegetables has over the years focused on diversity (Adebooye \& Ajayi, 2008), production and marketing (Pasquini \& Young, 2007; Shiundu \& Oniang'o, 2007), role in poverty alleviation (Oladele, 2011; Weinberger \& Msuya, 2004). Livelihood diversification studies have tended to be preoccupied with studies on analysis of the determinants of income diversification strategies (Wanyama et al., 2010; Ibrahim \& Umar, 2008; Simtowe, 2010; Barrett, Bezuneh, Clay, \& Reardon, 2005). Shackleton, Pasquini, and Drescher (2009) explored ways by which indigenous vegetables can be promoted for urban agriculture and livelihood. There remains a shortage of empirical studies on livelihood diversification strategies among the producers (especially women) in Osun state that might inform a deeper understanding of the observed patterns of income sourcing among the female indigenous vegetable farmers. An understanding of livelihood diversification strategies of female indigenous vegetable farmers may serve as entry point for poverty reduction and women empowerment in the study area. Hence, this study seeks to provide answers to the following questions. What are the socioeconomic characteristics of the female indigenous vegetable farmers in Osun state? What are the income profiles of these farmers? What pattern of livelihood diversification strategies exist among the farmers?

\subsection{Objectives}

The broad objective of the study is to investigate the livelihood diversification strategies among female indigenous vegetable farmers in Osun state. Specifically, the study seeks to

1) Assess the socioeconomic characteristics of the female indigenous vegetable farmers in Osun state;

2) Investigate the income profile of the farmers;

3) Examine the pattern of livelihood diversification strategies.

\section{Methods}

\subsection{Sampling Technique}

Four-stage multistage sampling method was carried out. The first stage involved the selection of the three agricultural zones in Osun state as defined by the Osun State Agricultural Development Program. The selected 
zones are Osogbo zone - which is a derived savannah (divided into six blocks), Iwo zone - which is a guinea savannah (divided into seven blocks), and Ife/Ijesa zone - which is rainforest (divided into twelve blocks). The second stage involved the random selection of two local government areas (LGAs) each from Osogbo and Iwo zones while, four LGAs were selected from the Ife/Ijesha zone to achieve a proportionate spread across the three agricultural zones. In Osogbo, Osogbo and Olorunda LGAs were selected; in Iwo zone Ede North and Ayedaade LGAs was selected, while, in Ife/Ijesha zone Atakunmosa West, Ilesha West, Ife Central and Ife East LGAs were also selected. The third stage involved random selection of three communities from each of the LGAs. The identification of the communities where the female indigenous vegetable farmers could be found was achieved through the markets in each LGA. The fourth stage involved the purposive selection of 10 female indigenous vegetable growers from each community, using snowball sampling technique to give a total of 240 respondents. The selection is purposive because it aimed at respondents who are female and cultivated indigenous vegetables. In addition, snowball sampling technique involves identifying one or more female indigenous vegetable farmer, who in turn helps identify other respondents until the sample size is reached.

\subsection{Data Collection}

Primary data were generated through the use of structured questionnaire to elicit information on socio-economic characteristics of the farmers such as age, marital status, education level, family size employment status and type. Additional information collected include types and value of asset owned; components of farmers' incomes and total expenditure.

\subsection{Method of Data Analysis}

Descriptive statistics such frequency and percentage counts were used for the first specific objective. The second employed both descriptive and quartiles analysis while the third objective was achieved through the use of Simpson diversification index and cluster analysis.

The Simpson Index of Diversification, as adapted from Joshi et al. (2003) was given as

$$
\operatorname{SID}=1-\sum \mathrm{P}_{\mathrm{i}}^{2}
$$

Where,

$P_{i}$ is the proportion of income from source " $i$ ".

If there is just one source of income, $P_{i}=1$ and $\operatorname{SID}=0$. As the number of income sources increases, the share " $\mathrm{P}_{\mathrm{i}}$ " declines as does the sum of the squared shares, so that SID approaches 1. The closer SID is to zero, the more the specialization, and the further it is from zero, the greater the diversification.

The poverty line was used to classify the farmers into poor and non-poor to obtain the percentage poor included as an additional variable in the cluster analysis. Those farmers' whose consumption expenditure falls below the poverty line was classified as poor while those whose consumption expenditure is above the poverty line was classified as non-poor. The category of poverty line was given as:

Poor: Those spending $<2 / 3$ of MPCE;

Non poor: Those spending $\geq 2 / 3$ of MPCE;

$$
\mathrm{MPCE}=\text { Mean per capita expenditure }=\frac{P C E}{N}
$$

where,

$$
\mathrm{PCE}=\frac{\text { Total consumption expenditure }}{\text { Family size }} \text { and } \mathrm{N}=240 .
$$

\section{Results and Discussion}

Table 1 shows the mean age of the farmers to be 41.8 years with minimum age of 20 years and maximum age of 70 years. About $73 \%$ of the respondents were below 50 years of age implying that the sample were dominated by farmers active and economically productive farmers willing to explore new avenue for livelihood. $78 \%$ of the respondents are married. However, further examination revealed that only $24.6 \%$ were in a monogamous marriage while as much as $54.2 \%$ were in a polygamous marriage. This latter group reported that they work as part of the family labour on their husbands' farms. The return from the indigenous vegetable intercropped with other crops on these farms is a form of compensation for the labour expended. This formed the bulk of livelihood for the women and their children.

Education facilitates access to a number of different economic activities, either as a formal requirement for wage earning jobs or because it helps setting up and managing own small business (Minot, Epprecht, Anh, \& Trung, 
2006). Endowment in terms of education opens up opportunities for non-agricultural wage work. In Table 1, about $52 \%$ of the respondents had between 7 and 12 years of formal education indicating that more than half attained secondary school education. The lack of post-secondary education may limit farmers' access to high paying off-farm opportunities.

Family size represents the human-capital endowment of the farmers as it reflects potential labour supply. Table 1 shows that the majority (64.6\%) of the farmers had between 3 and 6 persons in their family, with mean value of about 5 persons. The family size of this magnitude may influence preference for farming activities given that family members and land are available for farming operations.

Access to land is critical for agricultural production. Table 1 showed that in the study area, farm size allocated to vegetable and other food crop ranged from 0.75 to 1.50 and 0.61 to 1.30 hectares respectively. Majority of the farmers cultivated less than 1 hectare in vegetable (65\%) and other food crops $(87.5 \%)$ production. About $73 \%$ of the respondents rented the land on which they farm, while only $25.8 \%$ of the respondents inherited their farm lands Hence, most of the farmers had temporary tenancy on their farm plots. This suggests constraint to access to land and small scale farming operations that may predispose farmers to augment income from farming activities with income from alternate sources in the study area.

Table 1. Socioeconomic characteristics of the female indigenous vegetable farmers in Osun State

\begin{tabular}{|c|c|c|c|c|c|c|c|}
\hline & Variables & Frequency & Percentage & Mean & Min. & Max & Standard Deviation \\
\hline (a) & Age & & & 41.8 & 20.0 & 70.0 & 11.9 \\
\hline \multirow[t]{7}{*}{ (b) } & Marital Status & & & & & & \\
\hline & Married Monogamous & 59 & 24.6 & & & & \\
\hline & Married Polygamous & 130 & 54.2 & & & & \\
\hline & Divorced & 3 & 1.3 & & & & \\
\hline & Widowed & 37 & 15.4 & & & & \\
\hline & Never Married & 11 & 4.6 & & & & \\
\hline & Total & 240 & 100 & & & & \\
\hline \multirow[t]{6}{*}{ (c) } & \multicolumn{7}{|c|}{ Educational Status } \\
\hline & $0-3$ & 96 & 40.0 & & & & \\
\hline & $4-6$ & 20 & 8.3 & & & & \\
\hline & $7-9$ & 81 & 33.8 & & & & \\
\hline & $10-12$ & 43 & 17.9 & & & & \\
\hline & Total & 240 & 100 & & & & \\
\hline \multirow[t]{7}{*}{ (d) } & \multicolumn{7}{|c|}{ Family size } \\
\hline & $0-2$ & 39 & 16.3 & & & & \\
\hline & $3-4$ & 69 & 28.7 & 4.8 & 1 & 10 & 2.1 \\
\hline & $5-6$ & 86 & 35.9 & & & & \\
\hline & $7-8$ & 41 & 17.1 & & & & \\
\hline & $9-10$ & 5 & 2.1 & & & & \\
\hline & Total & 240 & 100 & & & & \\
\hline (e) & \multicolumn{7}{|c|}{ Farm Size } \\
\hline \multicolumn{8}{|c|}{ Vegetable Farm Land } \\
\hline & $0-0.49$ & 86 & 35.8 & & & & \\
\hline & $0.5-0.99$ & 70 & 29.2 & 0.75 & 0.20 & 1.50 & 0.37 \\
\hline & $1.0-1.49$ & 84 & 35 & & & & \\
\hline \multicolumn{8}{|c|}{ Food Crop Farm Size } \\
\hline & 0 & 100 & 41.7 & & & & \\
\hline & $>0.5$ & 47 & 19.6 & 0.61 & 0.12 & 1.30 & 0.32 \\
\hline
\end{tabular}




\begin{tabular}{ccc}
\hline $0.5-0.9$ & 63 & 26.3 \\
$1.0-1.5$ & 30 & 12.5 \\
& & Mode of Land Acquisition \\
Inherited & 62 & 25.8 \\
Rented & 176 & 73.3 \\
Purchased & 2 & 0.8 \\
Total & 240 & 100 \\
\hline
\end{tabular}

Source: Field Data, 2012.

\subsection{Income Profile of the Respondents}

When linked to farm and off- farm activities in the rural areas, diversification is often used in describing the expansion in the importance of non-crop or non-farm income (M. Ijaiya, G. Ijaiya, Bello, M. Ijaiya, \& Ajayi, 2009). Evidence from Table 2 suggested that agricultural activities (production of vegetable, food crops, and livestocks) make up more than three quarters of total income, with income from vegetable production contributing half of the total income. This implies that less than a quarter of income $(21.89 \%)$ is generated from off-farm activities. This is contrary to the findings from Deininger and Olinto (2000) in Colombia that $50 \%$ of farmers' income was derived from off-farm endeavours. According to Babatunde and Qaim (2009), this less significant contribution of off-farm activities to total income suggests that distress-push effects are more important in this particular case.

Out of all the agricultural activities, vegetable production contributed exactly half of the total income of the respondents and is the most important source of income followed by income from food crop (23\%) which is produced by $57.9 \%$ of the respondents. Nearly three quarters of the farmers $(71.7 \%)$ participated in livestock rearing, albeit, its contribution (5.54\%) to total income is relatively small. Less than half of the farmers derived income from receipt of remittance (37\%) and off-farm activities (42.9\%), these sources only contributed $9.37 \%$ and $12.52 \%$ respectively to the total income.

The classification of off-farm employment followed Nghiem (2010) who classified off-farm employment as self-employed activities other than those related to crops, livestock and aquaculture production that takes place away from household-run farms. This classification also includes processing of any kind of goods for sale, whose input materials can be either home-produced agricultural commodities or bought from markets. Babatunde and Qaim (2009) also included agricultural and non-agricultural wage income and income from self-employed own businesses. Table 2 revealed that women farmers' income generation activities included petty trading (36.7\%), sales of agricultural produce (28.2\%), processing of agricultural crops (17.5\%) and few in artisanal occupation (13.5) and hiring out of labour (3.9\%). The petty trading was usually in ready-made clothings, food vending, beverages and provisions. Agricultural produce sold were fruits and vegetables, food stuff and locally processed foods. Those respondents who processed were engaged in processing of palm oil, cassava and other agricultural produce. A few (13.5\%) were skilled in tailoring and hairdressing and very few $(3.9 \%)$ worked as cleaners and storekeepers in private establishments. According to Ijaiya and Ijaiya (2009) and Adugna and Wagayehu (2008), diversification into non-farm activities such as off-farm wage labour, self-employment and transfer implies more diversity in income source.

Table 2. Income profile of the respondents

\begin{tabular}{|c|c|c|}
\hline Strategy & Frequency & Percentage \\
\hline \multicolumn{3}{|c|}{$\%$ Share in total income } \\
\hline Vegetable production & & 50.02 \\
\hline Food Crop production & & 22.55 \\
\hline Livestock production & & 5.54 \\
\hline Off farm occupation & & 12.52 \\
\hline Remittance & & 9.37 \\
\hline
\end{tabular}




\begin{tabular}{lll}
\hline \% Participation in livelihood strategies & & \\
Vegetable Production & 240 & 100 \\
Arable Crop Production & 139 & 57.9 \\
Livestock farming & 172 & 71.7 \\
Off farm Occupation & 103 & 42.9 \\
Remittance & 90 & 37.5 \\
Off farm occupation & & \\
Petty trade & 38 & 36.9 \\
Sales of Agricultural produce & 29 & 28.2 \\
Processing of agricultural crops & 18 & 17.5 \\
Artisanal occupation & 14 & 13.5 \\
Wage labour & 4 & 3.9 \\
\hline Total & $\mathbf{1 0 3}$ & $\mathbf{1 0 0}$ \\
\hline
\end{tabular}

Source: Field Survey, 2012.

\subsection{Share of Livelihood Activities Across the Quartiles.}

Table 3 shows how different income sources contributed to overall farmers' income across the quartiles. The first quartile represents the poorest while, the last represents the richest. The share of income from vegetable production is the highest in all the quartiles but this share reduces as total income increases. This means that its importance in livelihood portfolio decreases as income increases. On the contrary, the share of income from crop production increases across the quartile. Livestock, off farm activities and remittance account for a relatively small portion of the farmers' income. Though livestock production has the lowest percentage share in total income (from Table 2), income accrued from this source increases across the quartile. The almost constant income share of off farm activity may be taken as an indication of a stagnant off farm economy. Despite low share of transfer earnings in total income, poorer farmers still rely more on it than the richer ones. Nonetheless, the results demonstrated that the majority of the respondents in the study area maintained a diversified income portfolio.

Further examination revealed that land area available for agricultural production increases across the quartile. This implies that land is one of the important barriers to high income generation amongst the female indigenous vegetable farmers. Poorer farmers rely on vegetable farming to ensure sustenance because it generate quick returns with limited land available for cultivation while the higher income farmers have increasing income from crop due to increased access to land and the capability to engage in on-farm investment. This agrees with Haggblade, Hazell, and Reardon (2005) and Reardon and Taylor (1996) who opined that the poor rural farmers may embrace multiple livelihoods primarily to ensure survival, as they are forced to diversify mainly because they lack sufficient agricultural assets to sustain subsistence. On the other hand, higher income rural households with higher asset endowments will choose to diversify their livelihoods to maximize returns to their assets (Lay \& Schuler, 2007).

The diversification index also showed that rural livelihood diversification is higher among the richer than poorer farmers. This finding is comparable to those of Babatunde and Qaim (2009), Abdulai and Croleress (2001), and Block and Webb (2001) in (Kwara State) Nigeria, Mali and Ethiopia respectively. 
Table 3. Share of income from livelihood activities across the quartiles

\begin{tabular}{llllll}
\hline Economic Activities & I & II & III & IV & All \\
\hline Vegetable Production & 67.6 & 57.1 & 48.8 & 42.3 & 50.02 \\
Crop production & 10.8 & 20.3 & 23.6 & 26.2 & 22.55 \\
Livestock Production & 4.7 & 5.0 & 12.2 & 15.1 & 5.54 \\
\hline Off-Farm & 9.1 & 9.9 & 11.2 & 9.5 & 12.52 \\
Remittance & 7.7 & 7.7 & 4.1 & 7.0 & 9.37 \\
Total & 100 & 100 & 100 & 100 & 100 \\
Participation Rate in \% & & & & & \\
Vegetable Production & 100 & 100 & 100 & 100 & 100 \\
Crop production & 25 & 53.8 & 68.4 & 89.7 & 57.9 \\
Livestock Production & 61.7 & 61.5 & 71.9 & 93.1 & 71.7 \\
Off-Farm & 20 & 23.1 & 35.1 & 70.7 & 37.5 \\
Remittance & 23.3 & 27.7 & 45.6 & 55.2 & 42.9 \\
Other variables & & & & & \\
Total land area & 0.66 & 1.09 & 1.46 & 1.96 & \\
Investment on input & 17173.13 & 24987.88 & 30389.16 & 36340.08 & \\
Number of Income Sources & 1.3 & 1.66 & 2.21 & 3.1 & \\
Diversification index & 0.34 & 0.39 & 0.53 & 0.64 & \\
\hline
\end{tabular}

Source: Data Analysis, 2012.

\subsection{Pattern of Livelihood Diversification Strategies}

To be able to identify livelihood strategies, cluster analysis was employed in the classification of farmers' economic portfolio. To simplify, this study does not separate rental income because only $2 \%$ of the farmers reported this source. Following Iiyama, (2006) remittances are included as a category within off-farm income. This leaves four potential activity combinations. The result of the cluster analysis is presented in Table 4.

Cluster 1 represented the mixed smallholders whose farm operations integrated the production of vegetables, food crops and livestock. They allocated the second largest expanse of land ( 0.87 hectare) to food crop production and allocated only 0.76 hectare to vegetable production. They also had the second largest annual mean per capita income ( $\$ 308,359.60$ ) and a daily per capita income of $\$ 302.58$. About $19 \%$ of the poorest respondents belonged to this group. The relatively high mean per capital income may be closely linked with the potential that mixed farming has in reducing risk, spreading labour and re-utilizing resources, thereby supporting food, nutrition and cash security. De Weerdt (2009) also, in a study carried out in Tanzania, affirmed that the more successful people were those who have diversified their farming activities, growing food crops for their own consumption, crops for sale, and keeping livestock.

The second livelihood diversification strategy (cluster 2) combined vegetable production with livestock rearing. This strategy was employed by $16.25 \%$ of the total population. None of the farmers in this group allocated farm land to crop production but allocated about 0.70 hectare to vegetable production. The largest proportion of the poor was found in this group (29.63\%), having the least annual mean income ( $\$ 192,163.30)$ and subsisting on the lowest daily per capita income (\$156.23). Like Pica-Ciamarra, Tasciotti, Otte, and Zezza (2011), this findings revealed that poor farmers in lower quartiles are more likely to keep livestock than those in higher quartiles in order to achieve a balance between potential return and the risks associated with income variability (Alderman \& Paxsons, 1992). Dorward et al. (2005) opined that the savings, buffering and insurance functions of livestock in farmers' livelihood has long being recognised, however, its failure to boost sustenance above the poverty level for this group may be attributed to the fact that most farmers in the study area did not rear livestock as a conscious business endeavour.

Cluster 3, the sole vegetable farming, represented about $16 \%$ of the total sample. The group subsisted only on vegetable production and allocated mean land area of 0.71 hectare to it. This cluster also had the second largest 
proportion of the poor (22.2\%) of the six clusters with an annual mean income of $\$ 200,953.90$ and daily per capita income of $\$ 242.22$.

The farmers in cluster 4, part time vegetables and livestock strategy, were engaged in the production of vegetable and livestock like those in cluster 1 and 2, but they were more likely to supplement their on-farm income with some unskilled off farm employment than with food crop production or none at all. They represented the smallest proportion $(10 \%)$ of the total sample and allocated the smallest portion of land expanse $(0.57$ hectare $)$ to vegetable production and none to other food crops. They also had the annual mean income of $\$ 270,074$ and daily per capita income of $\$ 212.22$. Only $16.05 \%$ of the poor in the total sample were found in this group. These results implied land scarcity which led Karugia, Oluoch-Kosura, Nyikal, Odumbe, and Marenya (2006) to opine that agricultural activities may not remain the only source of income and therefore rural farmers may not climb out of poverty through growth in land productivity alone. They concluded that access to off-farm sector opportunities can offer the land poor farmers alternative source of livelihoods.

The fifth strategy is the arable crop farming, which involve the production of vegetables and other food crops. This group represented $12.50 \%$ of the whole sample. They allocated the second largest area to vegetable $(0.79 \%)$ and only 0.70 hectare to food crops. They also had the second largest daily mean per capita income ( $\mathrm{N} 329.95)$ and second lowest proportion of the poor (11.11\%). The annual mean income of this group is $\$ 285,491.27$.

The sixth strategy (cluster 6), part time mixed smallholders, representing the second largest of the six groups (18.33\%) augmented income from farming activities with income from off-employment. Hence, they are the most diversified of the whole strategy. They allocated the largest land area to vegetable ( 0.89 hectare) and food crop production ( 0.94 hectare). They also had the highest annual mean ( $\$ 479,416.19)$ and the daily per capita income ( 378.55) as well as the smallest proportion of the poor (2.47\%). Apata, Igbalajobi, and Awoniyi (2010) and Gebru and Beyene (2012), amongst others, supported the claim that multiple income sources enhance welfare of rural farmers.

Table 4. Livelihood strategies estimated via k-means cluster analysis

\begin{tabular}{|c|c|c|c|c|c|c|}
\hline Clustering Variables & $\begin{array}{c}\text { Cluster 1 } \\
\text { (mixed } \\
\text { smallholders) }\end{array}$ & $\begin{array}{c}\text { Cluster } 2 \\
\text { (vegetables } \\
\text { and livestock } \\
\text { farmers) }\end{array}$ & $\begin{array}{c}\text { Cluster } 3 \\
\text { (sole vegetable } \\
\text { farmers) }\end{array}$ & $\begin{array}{c}\text { Cluster4 } \\
\text { (part time } \\
\text { vegetable and } \\
\text { livestock } \\
\text { farmers) }\end{array}$ & $\begin{array}{l}\text { Cluster } 5 \\
\text { (arable } \\
\text { crop } \\
\text { farmers) }\end{array}$ & $\begin{array}{c}\text { Cluster6 } \\
\text { (part time } \\
\text { mixed } \\
\text { smallholders) }\end{array}$ \\
\hline Vegetables & 1.00 & 1.00 & 1.00 & 1.00 & 1.00 & 1.00 \\
\hline Arable Cropping & 1.00 & 0.00 & 0.00 & 0.00 & 1.00 & 1.00 \\
\hline Livestock & 1.00 & 1.00 & 0.00 & 1.00 & 0.00 & 1.00 \\
\hline Off farm & 0.00 & 0.00 & 0.00 & 1.00 & 0.00 & 1.00 \\
\hline \multicolumn{7}{|l|}{ Other Variables } \\
\hline$\%$ of farmers & $27.08 \%$ & $16.25 \%$ & $15.83 \%$ & $10.00 \%$ & $12.50 \%$ & $18.33 \%$ \\
\hline Mean Food Crops Farm Size(Ha) & 0.87 & 0 & 0 & 0 & 0.70 & 0.94 \\
\hline Mean Vegetable Farm Size(Ha) & 0.76 & 0.70 & 0.71 & 0.57 & 0.79 & 0.89 \\
\hline$\%$ of the poor & $18.52 \%$ & $29.63 \%$ & $22.22 \%$ & $16.05 \%$ & $11.11 \%$ & $2.47 \%$ \\
\hline Annual Mean Income ( & 308359.60 & 192163.30 & 200953.90 & 270074.00 & 285491.27 & 479416.19 \\
\hline Daily per capital income $(\mathbb{)})$ & 302.58 & 156.23 & 242.22 & 212.22 & 329.95 & 378.55 \\
\hline
\end{tabular}

Source: Data Analysis, 2012.

\subsection{Distribution of Respondents in the Income Quartiles Across Income Portfolio}

Table 5 summarized the distribution of farmers into various income quartiles across the various income portfolio. The distribution trend is from first to the fourth quartile with the first quartile representing the lowest income group. The results indicated that vegetable production or its combination with livestock production predominated among the poorest farmers ( $47.37 \%$ and $53.85 \%$ respectively). Part time mixed farming seemed to be most successful as it has the highest proportion of the rich $(72.73 \%)$ and the lowest proportion of the poor $(4.55 \%)$. These findings 
generally agree with those of previous studies in countries of Sub-Sahara Africa, which have shown that richer households have more diversified livelihood strategies, while full time farming is more common among poorer households (Brown, Stephens, Ouma, Murithid, \& Barrette 2006; Barrett et al., 2005; Damite \& Negatu, 2004). Further examination of Table 5 revealed that multiplicity of activities increases income.

Table 5. Percentage distribution of respondents in the income quartiles across clusters

\begin{tabular}{cccccc}
\hline Cluster & I & II & III & IV & Total \\
\hline Mixed Smallholders & 10.77 & 26.15 & 41.54 & 21.54 & 65 \\
Vegetable and livestock farmers & 53.85 & 20.51 & 17.95 & 7.69 & 39 \\
Sole Vegetable Farmers & 47.37 & 39.47 & 13.16 & 0 & 38 \\
Part time Vegetable and Livestock Farmers & 25.00 & 29.12 & 29.12 & 16.67 & 24 \\
Arable Crop Farmers & 40.00 & 33.33 & 36.67 & 13.33 & 30 \\
Part time Mixed smallholder & 4.55 & 6.82 & 15.91 & 72.73 & 44 \\
Total & 100 & 100 & 100 & 100 & 240 \\
\hline
\end{tabular}

Source: Data Analysis, 2012.

\section{Conclusion and Recommendations}

Female indigenous vegetable farmers augument returns from vegetable production with income other economic activities. These sources of income do not have the same potential contribution to income. Hence, this study investigated them and their contribution to farmers' income. The study shed light on the socioeconomic characteristics of the female indigenous vegetable farmers in Osun state, their income profile and the pattern of livelihood diversification strategies that exist among them. The study was carried out among 240 female indigenous vegetable farmers. Information elicited from the respondents include socioeconomic characteristics of the farmers such age, marital status; components of farmers' incomes and total expenditure. The data collected was analysed with the aid of descriptive statistics, quartile and cluster analyses.

The results shows that the majority of the farmers were below 50 years of age, married, having a minimum of primary school education and cultivating less than 1 hectare of land. Income profile of the farmers indicated that, though, vegetable production ranked as the most important source of income as returns from it represented exactly half of the total income, it was not sufficient to sustain their livelihood throughout the year. Vegetable production as a livelihood strategy is distress-push because its share in total earnings reduces as income increases. Though low in income share, the trend of income accruing from livestock production increases across the quartile. The almost constant income share of off farm activity may be taken as an indication of a stagnant off farm economy. Pattern of livelihood diversification strategies identified by cluster analysis include sole vegetable farming, vegetable and livestock farming, part time vegetable and livestock farming, mixed farming, arable crop farming, and part time mixed farming. A livelihood diversification strategy that combines multiple portfolios demonstrably yields higher income for the farmers.

It is recommended that the farmers should intensify livestock production in the livelihood portfolio as a conscious business endeavour. The farmers should integrate on-farm activities with off-farm investments, especially those that have complementarity with farming activities such as milling and other food processing activities, to enable them increase income.

\section{Acknowledgements}

The fieldwork of this study is undertaken with the support of The Canadian International Food Security Research Fund (CIFSRF) which is a program of Canada's International Development Research Centre (IDRC) undertaken with the financial support of the Government of Canada provided through Foreign Affairs, Trade and Development Canada (DFATD).

\section{References}

Abdulai, A., \& CroleRees, A. (2001). Determinants of income diversification amongst rural households in Southern Mali. Food Policy, 26, 437-452. http://dx.doi.org/10.1016/S0306-9192(01)00013-6 
Adebooye, O., \& Ajayi, O. (2008). Future of the Nigerian under-exploited indigenous fruits and vegetables in the era of climate change: The Need for farmers Education. Conference on International Research on Food Security, Natural Resource Management and Rural Development. Tropentag 2008 University of Hohenheim, October 7-9, 2008.

Adebooye, O., \& Opabode, J. (2004). Status of conservation of the indigenous leaf vegetables and fruits of Africa. African Journal of Biotechnology, 3(12), 700-705. Retrieved from http://www.academicjournals.org/AJB

Adhikari, R. (2006). Economic dimension of empowerment: Effects of commercialization and feminization of vegetable farming on social status of women in an urban fringe of Western Nepal. Himalayan Journal of Sociology \& Anthropology, III, 1498-5663-1.

Adugna, E., \& Wagayehu, B. (2008). Livelihood Strategies and its determinants in Southern Ethiopia. The case of Boloso Sore of Wolaita zone. Retrieved May 1, 2011, from http:/www.articlesbase.com/college-and-university-articles/livelihood-strategies-and-its-determinants-in-so uthern-ethiopia-1410579.html\#ixzzlf4VEGCDq

Alderman, H., \& Paxson, C. (1992). Do the Poor Insure? A Synthesis of the Literature on Risk and Consumption in Developing Countries. Policy Research Working Paper 1008. World Bank, Washington D.C.

Apata, T., Apata, O., Igbalajobi, O., \& Awoniyi, S. (2010). Determinants of rural poverty in Nigeria: Evidence from small holder farmers in South-western, Nigeria. Journal of Science and Technology Education Research, 1(4), 85-91. Retrieved September, 2010, from http://www.academicjournals.org/JSTER

Aphane, J., Chadha, M., \& Oluoch, M. (2002). Increasing the consumption of micronutrient-rich foods through production and promotion of indigenous foods. In FAO-AVRDC International Workshop Proceedings Arusha, 2002 AVRDC-Regional Center for Africa, pp. 105-112.

AVDRC. (2011). The World Vegetable Centre. Retrieved June 6, 2011, from http://www.avrdc.org/index.php?

Babatunde, R., \& Qaim, M. (2009). Pattern of income diversification in rural Nigeria: Determinants and impacts. Quarterly Journal of International Agriculture, 48(4), 305-320.

Barrett, C., Bezuneh, M., Clay, D., \& Reardon, T. (2005). Heterogeneous constraints, incentives and income diversification strategies in rural Africa. Quarterly Journal of International Agriculture, 44(1), 37-60.

Besong, M., Samalang, P., \& Abia, C. (2001). Commercialisation as an incentive and threat for Gnetumspp in Cameroon. Incentive measures for sustainable use and conservation of agrobiodiversity: Experiences and lessons from Southern Africa (pp. 69-90). Proceedings of a Workshop Lusaka-Zambia.

Block, S., \& Webb, P. (2001). The dynamics of livelihood diversification in post-famine Ethiopia. Food Policy, 26(4), 333-350. http://dx.doi.org/10.1016/S0306-9192(01)00015-X

Brown, D., Stephens, E., Ouma, J., Murithid, F., \& Barrette, C. (2006). Livelihood Strategies in the Rural Kenyan Highlands. African Journal of Agricultural and Resource Economics, 1(1), 21-35.

Damite, D., \& Negatu, W. (2004). Determinants of rural livelihood diversification: Evidence from Southern Ethiopia. Quarterly Journal of International Agriculture, 43(3), 267-288.

De Weerdt, J. (2009). Moving out of Poverty in Tanzania: Evidence from Kagera. Journal of Development Studies.

Deininger, K., \& Olinto, P. (2000). Rural nonfarm employment and income diversification in Colombia. World Dev., 29(3), 455-465. http://dx.doi.org/10.1016/S0305-750X(00)00106-6

Dorward, A., Anderson, S., Nava, Y., Pattison, J., Paz, R., ... Rushton, J. (2005). A Guide to Indicators and Methods for Assessing the Contribution of Livestock Keeping to the Livelihoods of the Poor (p. 6). Department of Agricultural Sciences, Imperial College London.

Doss, C. (2005). The effects of intra household property ownership on expenditure patterns in Ghana. Journal of African Economies, 15(1), 149-180. http://dx.doi.org/10.1093/jae/eji025

Farm Concern International (FCI). (2011). The value networks and marketing systems. Retrieved May 7, 2011, from http://www.familyconcern.net/mod.php?topic=16\&cmu=35

Gebru, G., \& Beyene, F. (2012). Rural household strategies in drought-prone areas: A case of Gulomekeda district, eastern zone of Tigray national regional state, Ethiopia. Journal of Development and Agricultural Economics, 4(6), pp.158-168. 
Haggblade, S., Hazell, P., \& Reardon, T. (2005). The rural non-agricultural economy: pathway out of poverty or pathway in? International Food Policy Research Institute and Michigan State University, proceedings of the research workshop 'The Future of Small-Farms', June 26-29, UK, 2005.

Howard, P. (2003). Women and the plant world: An exploration. In P. L. Howard (Ed.), Women \& Plants: Gender Relations in Biodiversity Management and Conservation (pp. 1-48). New York and London: Zed Books and St Martin's Press.

Ibrahim, H., \& Umar, H. (2008) Determinants of poverty among farming households in Nasarawa state, Nigeria. PAT, 4(1), 11-21. Retrieved May 6, 2011, from http://www.patnsukjournal.com/current_issue

IITA. (2003). Pass the Leafy Veggies Please. iNew Science in Africa Magazine. Science in Africa. Merck Article. November, 2003.

Iiyama, M. (2006). Livelihoods diversification patterns among households and their implications on poverty and resource use: A Case Study from a Kerio river basin community. The Land Use Change, Impacts and Dynamics (LUCID) Project Working Paper Series, No. 51.

Ijaiya, M., Ijaiya, G., Bello, R., Ijaiya, M., \& Ajayi, M. (2009). Income diversification and household well-being in Ilorin metropolis, Nigeria. International Journal of Business Management, Economics and Information Technology, 1(1), 1-12.

Joshi, P., Gulati, A., Birthal, P., \& Twari, L. (2003). Agricultural diversification in South Asia: Patterns, determinants, and policy implications. Discussion Paper No. 57. Markets and Structural Studies Division. International Food Policy Research Institute. Washington, D.C.

Joshi, P., Joshi, L., \& Birthal, P. (2006). Diversification and Its Impact on Smallholders: Evidence from a study on vegetable production. Agricultural Economics Research Review, 19, 219-236.

Karugia, J., Oluoch-Kosura, W., Nyikal, R., Odumbe, M., \& Marenya, P. (2006). Access to land, income diversification and poverty reduction in rural Kenya. A paper presented at the International Association of Agricultural Economists Conference, Gold Coast, Australia, August 12-18, 2006.

Lay, J., \& Schüler, D. (2007). Income diversification and poverty in a growing agricultural economy: The case of Ghana. A draft paper. Kiel Institute for the World Economy. University of Göttingen.

Luchen, S., \& Mingochi, D. (1995). Traditional vegetables in Zambia: Genetic resources, cultivation and uses. Proceedings of the IPGRI International Workshop on Genetic Resources of Traditional vegetables in Africa: Conservation and Use (pp. 29-31). ICRAF-HQ, Nairobi Kenya.

Maroyi, A. (2011). Potential role of traditional vegetables in household food security: A case study from Zimbabwe. African Journal of Agricultural Research, 6(26), 5720-5728.

Minot, N., Epprecht, M., Anh., T., \& Trung, L. (2006). Income diversification in the northern uplands of Vietnam. Research report No.145. International Food Policy Research Institute, Washington D.C.

Nghiem, L. T. (2010). Activity and income diversification: trends, determinants and effects on poverty reduction the case of the Mekong River Delta. (An unpublished doctoral dissertation). Erasmus University Rotterdam.

Ngugi, I., Gitau, R., \& Nyoro, J. (2006). Regoverning Markets: Access to high value markets by smallholder farmers of African indigenous vegetables in Kenya. Tegemeo Institute, Egerton University, Kenya.

Nwachokor, M., Uzu, F., \& Molindo, W. (2009). Variations in physicochemical properties and productivity implications for four soils in the derived savannah of southern Nigeria. American-Eurasian Journal of Agronomy, 2(3), 124-129.

Olabiyi, T., Olayiwola, A., \& Oyediran, G. (2009). Influence of soil textures on distribution of phytonematodes in the south western Nigeria. World Journal of Agricultural Sciences, 5(5), 557-560.

Oladele, O. (2011). Contribution of Indigenous vegetables and fruits to poverty alleviation in Oyo state, Nigeria. $J$ Hum Ecol, 34(1), 1-6.

Onyango, C., Imungi, J., Mose, L., Harbinson, J., \& Van Kooten, O. (2009). Feasibility of commercial production of amaranth leaf vegetable by small scale farmers in Kenya. African Crop Science Conference Proceedings, 9. 767-772.

Pasquini, M., \& Young, E. (2007). Networking to promote the sustainable production and marketing of indigenous vegetables through urban and peri-urban agriculture in Sub-Saharan Africa (IndigenoVeg). Proceedings of 
the International Conference on Indigenous Vegetables and Legumes. Prospectus for Fighting Poverty, Hunger and Malnutrition. Acta Horticulturae 752, ISHS.

Pica-Ciamarra, U., Tasciotti, L., Otte, J., \& Zezza, A. (2011). Livestock assets, livestock income and rural households: Cross-country evidence from households (p. 6). Joint paper of the World Bank, FAO, AU- IBAR, ILRI.

Price, L., \& Ogle, B. (2008). Gathered indigenous vegetables in mainland Southeast Asia: A gender asset. Gender and natural resource management. IDRC Web Archives.

Quisumbing, A., \& Maluccio, J. (2000). Intra household allocation and gender relations: new empirical evidence from four developing countries. Washington, DC, IFPRI.

Reardon, T., \& Taylor, J. (1996). Agroclimactic shock, income inequality, and poverty: Evidence from Burkina Faso, World Development, 24(5), 901-914. http://dx.doi.org/10.1016/0305-750X(96)00009-5

Shackleton, C., Pasquini, M., \& Drescher, A. (2009). African indigenous vegetables in urban agriculture: Recurring themes and policy lessons for the future. In C. M. Shackleton, M. Pasquini, \& A. W. Drescher (Eds.), African Indigenous Vegetables in urban agriculture (pp. 271-284). London: Earthscan.

Shiundu, K., \& Oniang'o, R. (2007). Marketing African leafy vegetables, challenges and opportunities in the Kenyan context. African Journal of Food Agriculture Nutrition and Development, 17, 4-12.

Simtowe, F. (2010). Livelihoods diversification and gender in Malawi. African Journal of Agricultural Research, 5(3), 204-216. Retrieved from http://www.academicjournals.org/AJAR

Smith, L., Ramakrishnan, U., Ndiaye, A., Haddad, L., \& Martorell, R. (2003). The importance of women's status for child nutrition in developing countries. Research Report No. 131.Washington, DC, IFPRI.

Wanyama, M., Mose, L., Odendo, M., Okuro, J., Owuor, G., \& Mohammed, L. (2010). Determinants of income diversification strategies amongst rural households in maize based farming systems of Kenya. African Journal of Food Science, 4(12), 754-763. Retrieved from http://www.academicjournals.org/ajfs

Weinberger, K., \& Lumpkin, T. (2005). High value agricultural products in Asia and the Pacific for smallholder farmers: Trends, opportunities and research priorities. Rome: GFAR. Retrieved from $\mathrm{http} / / /$ www.egfar.org/documents/02_-_Meetings/Workshops/Workshop_on_High_Value_Products_Oct_20 05/regional_AP.pdf

Weinberger, K., \& Msuya, J. (2004). Indigenous Vegetables in Tanzania - Significance and Prospects. Shanhua, Taiwan: AVRDC - The World Vegetable Center. Technical Bulletin, 31, 70.

\section{Copyrights}

Copyright for this article is retained by the author(s), with first publication rights granted to the journal.

This is an open-access article distributed under the terms and conditions of the Creative Commons Attribution license (http://creativecommons.org/licenses/by/3.0/). 